\title{
PENERAPAN SANKSI HUKUM BAGI PARA ADVOKAT PELAKU TINDAK PIDANA SUAP DALAM SISTEM HUKUM POSITIF DI INDONESIA ${ }^{*}$
}

\author{
Hartono \\ Fakultas Hukum, Universitas Surabaya \\ Griya Citra Asri RM 21 No. 10 Surabaya, Jawa Timur \\ e-mail: hartono.tonz77@gmail.com
}

\begin{abstract}
Current bribery is very much happening in various regions of Indonesia and this can be seen from the increasingly widespread acts of abuse and abuse of the authority of law enforcement officers and can not be separated from the various things that make the occurrence of various bribery and wrong actions the other is done by Advocates who are part of one of the law enforcement officers in Indonesia, Advocates should be an example for the community and other law enforcement officials to obey and enforce the law. This research was conducted using normative juridical and statute approach, conducting studies on applicable laws and regulations and other regulations relating to the subject matter discussed in this research. The results of this study indicate that the application of sanctions to Advocates as perpetrators of bribery is subject to criminal penalties as stipulated in (Criminal Law, bribery law andthe law to eradicate corruption) and also the application of sanctions for Advocates' Code of Ethics.
\end{abstract}

Keyword: Criminal Acts; Bribery; Corruption; Advocate; Sanctions.

\begin{abstract}
Abstrak
Tindak pidana suap pada saat ini sangat banyak sekali terjadi di berbagai wilayah di Indonesia dan hal ini dapat terlihat dari semakin maraknya tindakan-tindakan melanggar dan penyalahgunaan kewenangan aparat penegak hukum dan tidak terlepas dari adanya berbagai hal yang membuat terjadinya berbagai aksi-aksi penyuapan dan salah satunya dilakukan oleh Advokat yang merupakan bagian dari salah satu aparat penegak hukum di Indonesia yang seharusnya adalah menjadi teladan bagi masyarakat dan aparat penegak hukum lainnya untuk taat dan menjalankan tegaknya hukum. Penelitian ini dilakukan dengan menggunakan yuridis normatif dan dengan pendekatan perundang-undangan (statute approach), melakukan kajian-kajian terhadap peraturan perundang-undangan yang berlaku dan peraturan lainnya yang berkaitan dengan pokok masalah yang dibahas dalam penelitian ini. Hasil dari penelitian ini menunjukan bahwa penerapan sanksi terhadap Advokat sebagai pelaku tindak pidana suap dijatuhi hukuman pidana sebagaimana yang diatur dalam (KUHP, UU TPS dan UU PTPK) dan juga penerapan sanksi Kode Etik Advokat.
\end{abstract}

Kata Kunci: Tindak Pidana; Suap; Korupsi; Advokat; Sanksi.

\footnotetext{
* Naskah diterima: 26 Juli 2019, direvisi: 5 September 2019, disetujui untuk terbit: 30 September 2019

Doi: 10.3376/jch.v5i1.181
} 


\section{PENDAHULUAN}

Indonesia adalah Negara yang sudah merdeka, Pancasila merupakan pandangan hidup dan ideologi dasar yang hingga saat ini tetap dianut oleh Negara Indonesia tanpa ada pengecualian sama sekali dalam menjalankan jalannya proses kehidupan sehari-hari. Dalam situasi roda kehidupan manusia di Indonesia dalam melakukaninteraksi sosial antara sesama manusia tentunya akan selalu berpatokan pada suatu norma, aturan atau tatanan hukum yang ada di tengah-tengah masyarakat. Norma, aturan dan tatanan hukum sangat diperlukan oleh setiap manusia untuk saling berinteraksi (Satjipto Raharjo, 2006: 13).

Pada sisi lain, tentunya norma, aturan atau tatanan hukum tersebut juga memerlukan adanya sanksi apabila dilanggar. Suatu sanksi hukum sangatlah diperlukan agar tercapai adanya kepastian, keadilan dan manfaat dari adanya aturan-aturan yang diberlakukan tersebut. Hal ini disebabkan bahwa tidak bisa dihindarkan masing-masing manusia signifikan memiliki kecenderungan untuk menyimpang dari norma, aturan atau tatanan hukum yang ada disebabkan oleh adanya hawa nafsu yang tidak bisa dikendalikan. Ketentuan Pasal 1 ayat 3 UUD 1945 menyatakan bahwa, Negara Indonesia adalah merupakan negara hukum. berdasarkan isi pasal tersebut, maka jelaslah bahwa semua kegiatan penyelenggaraan negara tidak akan terlepas dari peraturan perundangundangan termasuk dalam kegiatan penyelenggaraan peradilan di Indonesia.
Kepastian dan kesetaraan bagi setiap orang di hadapan hukum adalah salah satu prinsip Negara hukum itu sendiri. Dapat disimpulkan bahwa negara Indonesia tidak berdasarkan kekuasaan belaka, oleh karenanya segala tindakan dan kewenangan penguasa atau alat-alat perlengkapannya akan diatur oleh hukum juga, jadi kewenangan penguasa mempunyai batas-batas tertentu. Hukum sebagai pemandu dalam kehidupan bermasyarakat untuk menciptakan keamanan, ketertiban, keadilan, kepastian dalam suatu negara dan disertai adanya perlindungan atas hak asasi manusia (HAM) serta sebagai alat untuk menyelesaikan atas adanya kemungkinan konflik-konflik antar subjek-subjek hukum di Indonesia.

Salah satu sifat yang mendasar tentang Negara Hukum, yaitu terletak pada perlengkapannya yang selalu bertindak dan patuh terhadap peraturanperaturan yang sudah ditentukan setelah atau sebelumnya oleh alat perlengkapan yang dikuasakan untuk menerbitkan peraturan tersebut. Kesetaran dalam segala bidang dan peradilan yang tidak tercemar atas kekuasaan apapun, yang juga selalu menempatkan legalitas di tempat utama, menunjukkan bahwa Negara ini yang memiliki ciri-ciri khas sebagai negara hukum hingga saat ini.

Teori dan praktiknya, di dunia peradilan diperlukan adanya profesi advokat yang banyak dikenal oleh masyarakat dengan istilah Pengacara, Pembela atau Penasihat Hukum sebagai penyeimbang, agar dunia peradilan 
Hartono: Penerapan Sanksi Hukum Bagi Para Advokat Pelaku Tindak Pidana Suap...

terbebas dari campur tangan dan pengaruh dari luar dan itu adalah sebuah keharusan berdasarkan Undang-Undang yang ada berlaku di Indonesia. Advokat sebagai profesi yang bebas/tidak bisa diintervensi, mandiri/tidak terikat dan bertanggung jawab untuk membuat suatu peradilan yang jujur, adil dan memiliki kepastian hukum bagi semua pencari keadilan dalam menegakkan hukum, kebenaran, keadilan dan hak asasi manusia.Pembela sering disalahtafsirkan, seakan-akan berfungsi sebagai penolong Tersangka atau Terdakwa bebas atau lepas dari pemidanaan walaupun ia jelas bersalah melakukan yang didakwakan itu. Pada hakekatnya pembela atau penasihat hukum membantu Hakim untuk menemukan sebuah kebenaran materiil, walaupun bertolak dari sudut pandangan subjektif, yaitu berpihak kepada kepentingan tersangka atau terdakwa.

Advokat sebagai profesi yang bebas/tidak bisa diintervensi, mandiri/tidak terikat dan bertanggung jawab memiliki suatu peran yang penting untuk menciptakan atau mewujudkan prinsip-prinsip negara hukum dalam kehidupan bermasyarakat dan bernegara di Indonesia, di samping adanya keberadaan lembaga peradilan dan instansi penegak hukum seperti kepolisian dan kejaksaan terlebih lagi sejak diberlakukannya Undang-Undang Nomor 18 Tahun 2003 Tentang Advokat (UUA). Keberadaan Advokat adalah sebagai salah satu bagian unsur aparat penegak hukum di Indonesia. Advokat dalam menjalankan profesinya selalu berlandaskan atas hukum untuk mencapai suatu keadilan bagi kepentingan masyarakat.

Hukum itu berfungsi sebagai sarana untuk mewujudkan hukum itu sendiri, dan di dalam mewujudkan fungsi tersebut diperlukan perangkat pelaksana dalam penegakan hukum seperti Polisi, Jaksa, Hakim dan Advokat. Kebutuhan akan peran Advokat khususnya dalam proses peradilan akan semakin meningkat sejalan dengan kebutuhan hukum bagi masyarakat luas terutama di era globalisasi ini. Selain itu semua, seiring dengan perkembangan hukum akibat adanya tuntutan akan meningkatnya kebutuhan dan kemajuan zaman seperti yang terlihat pada saat ini, masyarakat modern dalam memandang masalah hukum yang menimpa dirinya haruslah ditangani secara cepat, tepat dan profesional dengan memanfaatkan jasa ahli di bidang hukum yaitu Advokat.

Menurut ketentuan UUA, bahwa yang dimaksud Advokat adalah orang yang professional dalam bidangnya yang memberi jasa hukum, baik di dalam maupun di luar pengadilan dengan syaratsyarat yang telah diatur dalam ketentuan Pasal 3 UUA. Secara normatif, undangundang tersebut juga menegaskan bahwa Advokat adalah salah satu aparat penegak hukum yang ada di Indonesia yang memiliki kedudukan yang sama dengan penegak hukum lainnya seperti Polisi, Jaksa, dan Hakim. Perkembangan masyarakat mempengaruhi pola penegakan hukum, oleh sebab itu Advokat tidak pernah terlepas dari masalah penegakan hukum di Indonesia. 
Setiap Advokat dalam menjalankan setiap pekerjaannya harus tetap melaksanakan dan mematuhi ketentuan kode etik profesi yang berlaku.

Permasalahan pelik yang sangat sering terjadi dalam proses penegakan hukum di Indonesia sering terjadi karena para aparat penegak hukum itu sendiri, yang hakikatnya adalah mewujudkan penegakan hukum malah menjadi sebuah batu sandungan dalam sebuah peradilan. Salah satu contoh kasus Operasi Tangkap Tangan yang dilakukan oleh Komisi Pemberantasan Korupsi (KPK) terhadap aparat penegak hukum yaitu 3 (tiga) orang Hakim dan 1 (satu) orang Panitera PTUN Medan serta Advokat yang masih baru beracara dan bekerja di Kantor Advokat O.C. Kaligis sedang melakukan penyuapan dengan memberikan sejumlah uang dan perkembangannya menurut keterangan dan bukti-bukti yang ada, O.C. Kaligis yang sangat dikenal oleh masyarakat sebagai salah satu Advokat kondang dan populer dalam dunia hukum dan Advokat juga terlibat dalam kasus ini dalam hal penyuapan tersebut, dan hingga akhir inipun masih banyak pemberitaanpemberitaan terkait penyuapan yang dilakukan oleh Advokat di berbagai wilayah Indonesia.

Perkembangan zaman yang begitu pesat membuat hukum tidak lagi menjadi dasar dalam menegakkan keadilan dan ketertiban umum di Negara Indonesia. Banyak kasus hukum dijadikan sebagai proyek oleh aparat penegak hukum itu sendiri dan dapat disebut dengan istilah Mafia Peradilan yang melakukan berbagai cara dalam modus operandinya yaitu salah satunya dengan melakukan penyuapan yang mencederai rasa keadilan bagi semua lapisan masyarakat Indonesia terhadap aparat penegak hukum dalam setiap proses hukum yang terjadi dan hal ini berarti bahwa keadilan yang sesungguhnya sangat diharapkan di Indonesia justru telah menimbulkan masalah yang serius dalam penegakan hukum di Indonesia. Selama lembaga pengawas tidak bisa menjangkau ruang dan waktu yang digunakan oleh mereka yang berkepentingan dalam penanganan suatu perkara maka selama itu pula pelanggaran kode etik akan terus terjadi (Agus Raharjo \& Sunaryo, 2014)

Keterlibatan aparat penegak hukum dalam kasus korupsi merupakan fakta yang tak bisa di hindarkan lagi dalam melakukan setiap pekerjaannya, sekalipun mereka mengerti dan memahami hukum serta ancaman korupsi, tetap saja masih banyak yang terlibat khususnya keterlibatan Advokat sebagai pelaku tindak pidana suap di Indonesia. Memberantas tindakan yang sangat merugikan kita semua(korupsi) adalah tanggung jawab bersama seluruh komponen bangsa baik selaku individu, keluarga, masyarakat dan pemerintah. Pemerintah juga harus memberi pengetahuan dan kesadaran akan dampak negative yang di timbulkan dari perbuatan korupsi, sehingga pengetahuan masyarakat tentang perbuatan korupsi makin meningkat dan menumbuhkan keprihatinan dan sikap anti terhadap korupsi (RB. Soemanto, Sudarto, 
Hartono: Penerapan Sanksi Hukum Bagi Para Advokat Pelaku Tindak Pidana Suap...

Sudarsana, 2014). Tetapi kenyataannya hingga saat ini hal ini belum dipahami bersama sehingga memerlukan sosialisasi kepada seluruh kalangan masyarakat tentang tanggung jawab dan peran masing-masing untuk melenyapkan budaya korupsi di Indonesia khususnya tentang masalah suap menyuap dalam penanganan proses kasus hukum yang terjadi di Indonesia karena masalah korupsi adalah merupakan proses pembusukan yang dapat menghancurkan peradaban dan pembangunan nasional bangsa Indonesia.

Berangkat dari pendahuluan yang telah dikemukakan, penting bagi penulis untuk melakukan kajian karya ilmiah ini dengan suatu rumusan masalah yaitu pertama, Bagaimana pengaturan hukum tentang tindak pidana suap dalam preskriptif ketentuan hukum positif yang berlaku di Indonesia ?kedua, Bagaimanakah bentuk dan proses penerapan sanksi hukum bagi para Advokat selaku pelaku tindak pidana suap berdasarkan ketentuan hukum positif yang berlaku di Indonesia?

\section{METODE PENELITIAN}

Tipe yang digunakan dalam penelitian ini adalah tipe "Penelitian Hukum Normatif', yaitu suatu penelitian yang bertumpu pada telaah-telaah penelitian yuridis normatif atas hukum positif dan Undang-Undang yang sudah ada serta berlaku di Indonesia yang ada hubungannya dengan permasalahan dalam penulisan ini.
Penulis menggunakan pendekatan perundang-undangan (statute approach), yaitu pendekatan dengan melakukan kajian-kajian terhadap peraturan perundang-undangan yang berlaku(Peter Mahmud Marzuki, 2008: 93). Di samping itu, dalam penelitian ini juga menggunakan pendekatan-pendekatan pada doktrin/konsep para ahli hukum yaitu dengan tetap memperhatikan, mempelajari dan memahami pendapat dari para ahli hukum dalam karya-karya tulis ilmiah.

\section{HASIL DAN PEMBAHASAN}

\section{Pengaturan Hukum Tentang Tindak Pidana Suap Di Indonesia}

Setelah rezim pemerintahan Soeharto jatuh, telah terjadi babak baru yang ditandai dengan lahirnya era Reformasi untuk menggantikan era Orde Baru. Sistem pemerintahan sentralistik pada masa Orde Baru yang dianggap sebagai salah satu sumber maraknya praktik Kolusi, Korupsi dan Nepotisme (KKN) mulai ditinggalkan seiring dengan diterapkannya desentralisasi penyelenggaraan negara dalam bentuk Otonomi Daerah (Otda) maupun agenda reformasi dalam berbagai bidang untuk mewujudkan upaya pembangunan Nasional di Indonesia. Perubahan sistem tersebut tidak serta-merta dapat menghapus maraknya praktik $\mathrm{KKN}$ di Indonesia. Dapat dikatakan demikian, karena faktanya dengan berjalannya waktu praktik korupsi tidak semakin menurun, tetapi semakin meningkat. Dalam proses hukum di Indonesia, suap sangat identik sekali sering tampak 
dilakukan kepada Kepolisian, Jaksa dan Hakim.

Melihat hal ini, maka dapat dikatakan bahwa korupsi merupakan masalah serius, yang pemberantasannya harus dilakukan dengan sungguh-sungguh dengan segala upaya pemberantasan dan kebijakan pencegahan maupun penanggulangannya, khususnya tentang suap menyuap. Berbicara mengenai suap yang menjadi salah satu tindak pidana yang diatur di Indonesia, tidak terlepas dari pengertian suap itu sendiri. Suap pada umumnya di berbagai dunia dikenal dengan istilah "bribery" yang artinya pengemis atau gelandangan. Pengertian suap dalam KBBI menyebutkan bahwa, "suap" memiliki pengertian yaitu memberi makan ke dalam mulut ; meloloh ; uang sogok ; uang pelicin. "menyuap" memberi makan dengan memasukkan makanan ke dalam mulut ; menyogok, memberi uang untuk kemudahan urusan. Dengan demikian, maka kosakata yang lebih cocok adalah "uang sogok" atau "uang pelicin" dengan kata tambahan "memberi" yang artinya memberi uang sogok atau uang pelicin untuk kemudahan urusan.

Dalam perkembangannya di Indonesia, tindakan suap menyuap juga adalah merupakan bagian dari korupsi karena suap adalah merupakan suatu fenomena kejahatan yang perbuatannya sangat erat sekali kaitannya dengan pejabat atau aparat pemerintah karena pihak yang menerima suap (uang sogokan) dalam banyak kasus adalah pejabat atau aparat dengan harapan agar si penyuap dimudahkan atau mendapatkan janji kemudahan dalam tugas yang menjadi kewenangan pejabat atau aparat tersebut yang menimbulkan terjadinya perilaku-perilaku yang tercela dan tidak terkecuali menimbulkan adanya kebiasaan atau budaya yang buruk dalam penegakan hukum di Indonesia.

Pengaturan hukum yang dipergunakan mengenai pengaturan tindak pidana suap terdapat pada berbagai Undang-Undang yang jika di kelompokan menjadi 3 bagian yaitu :

1) Dalam Ketentuan Kitab UndangUndang Hukum Pidana (KUHP)

a) Pasal 209 KUHP

Dalam ketentuan pasal 209 ayat 1 KUHP, disebutkan bahwa:

"Dihukum dengan pidana penjara selama-lamanya dua tahun delapan bulan atau denda paling banyak empat ribu lima ratus rupiah:

1) Barangsiapa memberi atau menjanjikan sesuatu kepada seorang pejabat dengan maksud menggerakkannya untuk berbuat sesuatu dalam jabatannya yang bertentangan dengan kewajibannya;

2) Barangsiapa memberi sesuatu kepada seorang pejabat karena atau berhubung dengan sesuatu yang bertentangan dengan kewajiban, dilakukan atau tidak dalam jabatannya;".

b) Pasal 418 KUHP

Dalam ketentuan Pasal 418 KUHP, disebutkan bahwa :

"Seorang pejabat yang menerima hadiah atau janji padahal diketahui atau sepatutnya harus diduganya, bahwa hadiah atau janji itu diberikan 
Hartono: Penerapan Sanksi Hukum Bagi Para Advokat Pelaku Tindak Pidana Suap...

karena kekuasaan atau kewenangan yang berhubungan dengan jabatannya, atau yang menurut pikiran orang yang memberi hadiah atau janji itu ada hubungannya dengan jabatannya, diancam dengan pidana penjara paling lama enam bulan atau pidana denda paling banyak empat ribu lima ratus rupiah”.

c) Pasal 419 KUHP

Dalam ketentuan Pasal 419 KUHP, disebutkan bahwa :

"Diancam dengan pidana penjara paling lama lima tahun, seorang pejabat :

1) Yang menerima hadiah atau janji, padahal diketahuinya bahwa hadiah atau janji itu diberikan untuk menggerakkannya supaya melakukan atau tidak melakukan sesuatu dalam jabatannya, yang bertentangan dengan kewajibannya;

2) yang menerima hadiah mengetahui bahwa hadiah itu diberikan sebagai akibat atau oleh karena si penerima telah melakukan atau tidak melakukan sesuatu dalam jabatannya yang bertentangan dengan kewajibannya;".

d) Pasal 420 ayat 1 KUHP

Dalam ketentuan Pasal 420, disebutkan bahwa :

"Diancam dengan pidana penjara paling lama sembilan tahun :

1) Seorang hakim yang menerima hadiah atau janji, padahal diketahui bahwa hadiah atau janji itu diberikan untuk mempengaruhi putusan perkara yang menjadi tugasnya ;

2) Barangsiapa menurut ketentuan undang-undang ditunjuk menjadi penasihat untuk menghadiri sidang pengadilan, menerima hadiah atau janji, padahal diketahui bahwa hadiah atau janji itu diberikan untuk mempengaruhi nasihat tentang perkara yang harus diputus oleh pengadilan itu ;".

e) Pasal 420 ayat 2 KUHP

Dalam ketentuan Pasal 420 ayat 2 KUHP, disebutkan bahwa :

"Jika hadiah atau janji itu diterima dengan sadar, bahwa hadiah atau janji itu diberikan supaya dipidana dalam suatu perkara pidana, maka yang bersalah diancam dengan pidana penjara paling lama dua belas tahun;".

2) Dalam Ketentuan Undang-Undang Republik Indonesia Nomor 11 Tahun 1980 Tentang Tindak Pidana Suap (UU TPS)

Dalam ketentuan Pasal 3 UU TPS, disebutkan bahwa :

"Barangsiapa menerima sesuatu atau janji, sedangkan ia mengetahui atau patut dapat menduga bahwa pemberian sesuatu atau janji itu dimaksudkan supaya ia berbuat sesuatu dalam tugasnya, yang berlawanan dengan kewenangan dan kewajibannya yang menyangkut kepentingan umum, dipidana karena menerima suap dengan pidana penjara selama-lamanya 3 (tiga) tahun atau denda sebanyakbanyaknya Rp. 15.000.000,- (lima belas juta rupiah)"'.

3) Dalam Ketentuan Undang-Undang Republik Indonesia Nomor 20 Tahun 2001 Tentang Perubahan Atas Undang-Undang Republik 
Indonesia Nomor 31 Tahun 1999 Tentang Pemberantasan Tindak Pidana Korupsi (UU PTPK)

a) Pasal 5 ayat (1) UU PTPK Dalam ketentuan Pasal 5 ayat (1) UU PTPK, disebutkan bahwa :

1) dipidana dengan pidana penjara paling singkat 1 (satu) tahun dan paling lama 5 (lima) tahun dan atau denda paling sedikit Rp.50.000.000,- (lima puluh juta rupiah) dan paling banyak $\mathrm{Rp}$. 250.000.000,- (dua ratus lima puluh juta rupiah) setiap orang yang :

a. memberi atau menjanjikan sesuatu kepada pegawai negeri atau penyelenggara negara dengan maksud supaya pegawai negeri atau penyelenggara negara tersebut berbuat atau tidak berbuat sesuatu dalam jabatannya, yang bertentangan dengan kewajibannya ; atau

b. memberi sesuatu kepada pegawai negeri atau penyelenggara negara karena atau berhubungan dengan sesuatu yang bertentangan dengan kewajiban, dilakukan atau tidak dilakukan dalam jabatannya ;

2) bagi pegawai negeri atau penyelenggara negara yang menerima pemberian atau janji sebagaimana yang dimaksud dalam ayat (1) huruf a atau huruf $b$, dipidana dengan pidana yang sama sebagaimana dimaksud dalam ayat (1);.

b) Pasal 6 UU PTPK

Dalam ketentuan Pasal 6 UU PTPK, disebutkan bahwa :

1. Dipidana dengan pidana penjara paling singkat 3 (tiga) tahun dan paling lama 15 (lima belas) tahun dan pidana denda paling sedikit Rp. 150.000.000,- (seratus lima puluh juta rupiah) dan paling banyak Rp. 750.000.000,- (tujuh ratus lima puluh juta rupiah) setiap orang yang :

a. Memberi atau menjanjikan sesuatu kepada hakim dengan maksud untuk mempengaruhi putusan perkara yang diserahkan kepadanya untuk diadili ; atau

b. Memberi atau menjanjikan sesuatu kepada seseorang yang menurut ketentuan perundang-undangan

ditentukan menjadi advokat untuk menghadiri sidang pengadilan dengan maksud untuk mempengaruhi nasihat atau pendapat yang akan diberikan berhubung dengan perkara yang diserahkan kepada pengadilan untuk diadili ;

2. Bagi hakim yang menerima pemberian atau janji sebagaimana yang dimaksud dalam ayat (1) huruf a atau advokat yang menerima pemberian atau janji sebagaimana dimaksud dalam ayat (1) huruf $b$, dipidana dengan pidana yang sama sebagaimana dimaksud dalam ayat (1) :.

c) Pasal 11 UU PTPK

Dalam ketentuan Pasal 11 UU PTPK, disebutkan bahwa :

"Dipidana dengan pidana penjara paling singkat 1 (satu) tahun dan paling lama 5 (lima) tahun dan atau pidana denda paling sedikit Rp. 50.000.000,- (lima puluh juta rupiah) dan paling banyak Rp. 250.000.000,(dua ratus lima puluh ribu rupiah) pegawai negara atau penyelenggara negara yang menerima hadiah atau janji padahal diketahui atau patut diduga, bahwa hadiah atau janji tersebut diberikan karena kekuasaan atau kewenangan yang berhubungan 
Hartono: Penerapan Sanksi Hukum Bagi Para Advokat Pelaku Tindak Pidana Suap...

dengan jabatannya atau menurut pikiran orang yang memberikan hadiah atau janji tersebut ada hubungan dengan jabatannya".

d) Pasal 12 huruf a, b, c dan d UU PTPK

Dalam ketentuan Pasal 12 UU PTPK, disebutkan bahwa :

"Dipidana dengan pidana penjara seumur hidup atau pidana penjara paling singkat 4 (empat) tahun dan paling lama 20 (dua puluh) tahun dan pidana denda paling sedikit Rp. 200.000.000,- (dua ratus juta rupiah) dan paling banyak Rp. 1.000.000.000,- (satu milyar rupiah) :

a. Pegawai negeri atau penyelenggara negara yang menerima hadiah atau janji, padahal diketahui atau patut diduga bahwa hadiah atau janji tersebut diberikan untuk menggerakkan agar melakukan sesuatu atau tidak melakukan sesuatu dalam jabatannya, yang bertentangan dengan kewajibannya ;

b. Pegawai negeri atau penyelenggara negara yang menerima hadiah padahal diketahui atau patut diduga bahwa hadiah tersebut diberikan sebagai akibat atau disebabkan karena telah melakukan atau tidak melakukan sesuatu dalam jabatannya yang bertentangan dengan kewajibannya;

c. Hakim yang menerima hadiah atau janji, padahal diketahui atau patut diduga bahwa hadiah atau janji tersebut diberikan untuk mempengaruhi putusan perkara yang diserahkan kepadanya untuk diadili ;

d. Seseorang yang menurut ketentuan peraturan perundangundangan ditentukan menjadi advokat untuk menghadiri sidang pengadilan, menerima hadiah atau janji, padahal diketahui atau patut diduga bahwa hadiah atau janji tersebut untuk mempengaruhi nasihat atau pendapat yang akan diberikan, berhubung dengan perkara yang diserahkan kepada pengadilan untuk diadili ;".

\section{e) Pasal 13 UU PTPK}

Dalam ketentuan Pasal 13 UU PTPK, disebutkan bahwa :

"Setiap orang yang memberi hadiah atau janji kepada pegawai negeri dengan mengingat kekuasaan atau wewenang yang melekat pada jabatan atau kedudukannya, atau oleh pemberi hadiah atau janji dianggap melekat pada jabatan atau kedudukan tersebut, dipidana dengan pidana penjara paling lama 3 (tiga) tahun dan atau denda paling banyak Rp. 150.000.000,- (seratus lima puluh juta rupiah)".

\section{Penerapan Sanksi Hukum Bagi Para Advokat Pelaku Tindak Pidana Suap Di Indonesia}

Agenda nasional Negara Indonesia mengenai pemberantasan korupsi, mafia hukum dan peradilan adalah merupakan bagian restorasi perubahan dan reformasi hukum bagi negara ini. Praktik KKN menimbulkan banyak penyimpangan dan merugikan keuangan negara serta perekonomian dan pembangunan nasional di Indonesia. Sedangkan mafia hukum dan peradilan adalah merupakan suatu kondisi dimana adanya suatu rekayasa yang terjadi di dalam proses peradilan sehingga proses hukum yang dimulai sesuai koridornya menghasilkan putusan yang tidak sesuai dengan yang seharusnya 
diputuskan dan sangat tidak sesuai dengan keadilan yang seharusnya ditegakkan sehingga rasa keadilan seolah-olah terinjak-injak akibat terjadinya praktekpraktek kotor dan bersifat curang dan salah satunya adalah praktek-praktek penyuapan yang justru dilakukan oleh Advokat baik dilakukan karena adanya permintaan secara langsung maupun karena atas inisiatif sendiri bersama dengan klien yang dibela Advokat tersebut dalam rangka memberikan kecepatan dalam hal proses penyelesaian, kepuasan dan kemenangan atas kasus hukum yang sedang dihadapi kliennya selaku pengguna jasa hukum Advokat.

Hukum dan keadilan adalah merupakan hal yang sangat universal dan mutlak menyentuh pembangunan hukum di Indonesia termasuk pemberantasan korupsi dan mafia hukum. Masalah hukum dan keadilan sudah menjadi persoalan yang hangat sejak zaman dahulu kala dan tampak seolah-olah tidak akan habis dipermasalahkan sepanjang masa. Tindak pidana suap yang dilakukan oleh Advokat baik dalam bentuk sebagai penyuapan aktif maupun penyuapan pasif sebagaimana disebutkan sebelumnya, maka melihat fenomena yang terjadi pada saat ini di Indonesia, pada kenyataannya dapat dikatakan bahwa Advokat lebih dominan dan signifikan menjadi Penyuap Aktif yaitu sebagai Pemberi Suap walaupun sebenarnya juga terlibat sebagai Penyuap Pasif di Indonesia.

Lord Acton menyatakan bahwa power tends to coruupt and absolute power corrupt absolutely .Tingginya suatu jabatan seseorang, berkorelasi dengan kesempatan untuk melakukan korupsi, dikarenakan orang yang memiliki jabatan yang tinggi lebih leluasa untuk melakukan penyimpangan/korupsi (Odie Faiz Guslan, 2018). Semakin banyaknya terungkap kasus penyuapan kepada Hakim, Panitera, Polisi, Jaksa dan pejabat pemerintah lainnya belakangan ini yang dilakukan oleh Advokat, tampaknya kepercayaan publik terhadap aparat penegak hukum telah menimbulkan stigma negatif buruk akibat ulah-ulah beberapa Advokat yang melakukan tindak pidana suap di Indonesia.

Saat ini penegakan prinsip akuntabilitas belumlah diterapkan sebagaimana mestinya. Akuntabilitas yang merupakan wujud penyampaian pertanggungjawaban dari para penerima amanah kepada pemberi amanah, belumlah memuaskan. Bilamana kesadaran akan akuntabilitas ini muncul, dan menjadi kebutuhan bagi para penyelenggara negara, maka korupsi dan nepotisme akan dengan sendirinya terminimalisir. Saat ini praktik- praktik akuntabilitas penyelenggaraan negara yang terjadi di Indonesia belumlah memuaskan. Banyak kalangan menilai bahwa akuntabilitas yang ada barulah sekedar untuk memenuhi ketentuan formalitas belaka, dengan demikian substansi dan hakekat akuntabiltas ini belumlah menggembirakan (Sjahruddin Rasul, 2014). Mustahil, untuk mengharapkan pemberantasan korupsi dan penegakan hukum dilaksanakan serta menjamin penyelenggaraan pemerintahan 
Hartono: Penerapan Sanksi Hukum Bagi Para Advokat Pelaku Tindak Pidana Suap...

yang tidak tercemar dari praktik-praktik $\mathrm{KKN}$, apabila Advokat yang notabenenya untuk menegakkan hukum justru melakukan praktik-praktik korupsi (tindak pidana suap) dan menjadi bagian dari persoalan itu sendiri.

Advokat dapat menjadi saluran untuk melahirkan korupsi, tetapi juga dapat sebagai individu yang dapat memberantas korupsi Advokat diharapkan sebagai "penjaga pintu" yang dimana diharapkan untuk dapat menfilter hal-hal yang dapat merusak tatanan hukum yang ada di Indonesia. Advokat dalam proses litigasi dengan sadar menghadapi dilema etika ketika Advokat sedang mewakili kliennya. Dalam perkara perdata memberikan sesuatu kepada hakim bukan tanpa kemungkinan untuk memenangkan perkara. Begitu juga dalam perkara pidana, mulai dari pemeriksaan di kepolisian, kejaksaan dan di depan Pengadilan, pemberian kepada mereka untuk meringankan, bahkan membebaskan tersangka atau terdakwa, di negeri kita, bukan hal yang tidak mungkin (Erman Rajagukguk, 2008).

Apabila dicermati secara umum, penyebab Advokat melakukan tindak pidana suap dikarenakan oleh beberapa faktor penyebab diantaranya yaitu sebagai berikut :

1. Faktor Budaya (berkaitan dengan kebiasaan memberikan sesuatu sebagai upeti yang telah dianggap sebagai hal yang biasa untuk balas budi atas suatu pekerjaan);

2. Faktor Prilaku Individu Advokat (sifat tamak, serakah dan rakus yang menjadikan profesinya sebagai alat untuk memenuhi kebutuhan primernya dan/atau memperkaya diri, moral yang kurang kuat, mudah tergoda atas permintaan dan pemberian, gaya hidup yang komsumtif, lingkungan kerja dan budaya organisasi yang mempengaruhi profesinya);

3. Faktor Birokrasi Pemerintahan (birokrasi pemerintahan dan peradilan yang rumit dan bertele-tele, lambat dan penuh dengan syarat prosedur menjadikan Advokat memilih jalan kompas dengan cara menyuap agar tidak dipersulit dan dipermudah waktunya);

4. Faktor Ekonomi (kebutuhan akan pekerjaan yang berjalan terus demi memenuhi kebutuhan hidup dengan melakukan segala cara termasuk memberi dan menerima suap);

5. Faktor Jabatan, Kekuasaan dan Wewenang (Advokat merasa ada kesempatan untuk mempergunakan profesinya sebagai aparat penegak hukum untuk melakukan segala cara baik menerima suap maupun memberi suap);

6. Faktor Penegakan Hukum (hukum di Indonesia belum memiliki kepastian, keadilan dan kemanfaatan dengan baik dan memberi celah sehingga Advokat berani melakukan tindakan penyuapan);

7. Faktor Pengawasan Organisasi Advokat (organisasi advokat seperti Perhimpunan Advokat Indonesia (PERADI) belum melakukan dengan sepenuhnya pengawasan dan 
penindakan secara tegas terhadap pelanggaran yang dilakukan oleh Advokat mengenai kode etik Advokat);

8. Faktor rendahnya Partisipasi Masyarakat (partisipasi seluruh masyarakat Indonesia untuk tidak melakukan praktik korupsi/suap sangat diperlukan dan adanya pengetahuan hukum bahwa melakukan suap adalah juga korupsi serta minimnya partisipasi untuk melakukan kepada Dewan Kehormatan atas pelanggaran kode etik Advokat yang terjadi).

Para Advokat yang terlibat dalam tipikor yang terjadi tidak lagi sekedar menjadi perantara suap, tetapi telah menjadi pelaku suap di Indonesia yang menggunakan cara apapun dalam menjalankan profesinya. Memerlukan pemahaman bahwa tindak pidana suap yang berhubungan dengan perlindungan hukum terhadap kelancaran tugas dan proses penegakan hukum di pengadilan beserta perlindungan hukum terhadap kepercayaan mengenai kebenaran hukum dari vonis hakim dengan diberikannya kebebasan hakim dalam proses peradilan menurut hukum pidana korupsi di Indonesia, atas dasar dari mana datangnya perbuatan yang menyerang kepentingan hukum tersebut. Kebijakan hukum pidana perlu dilakukan dengan pendekatan yang berorientasi pada kebijakan (policyoriented approach) yang lebih bersifat pragmatis, rasional dan berorientasi pada nilai (value judgement, apporach)bertujuan untuk menyelesaikan permasalahan korupsi, dan untuk melindungi kepentingan masyarakat (Vidya Prahassacitta, 2017).

Fungsionalisme korupsi membawa ke arah skeptisisme moral yang sempurna, mempertinggi semangat orang yang korup, dan memperburuk kekeroposan landasan yang menjadi nilai-nilai luhur selama ini (Muryanti, 2018). Melihat halhal tersebut maka dapat diambil suatu kesimpulan mengenai akibat tindak pidana suap yang di lakukan oleh Advokat yaitu sebagai berikut:

1. Merusak tatanan hukum dan ketahanan nasional Negara Indonesia;

2. Tidak tercapainya dan/atau terselenggaranya sistem pelayanan pemerintahan dengan baik, bersih dan lepas dari semua unsur $\mathrm{KKN}$ di Indonesia;

3. Menimbulkan terjadinya Mafia Hukum atau Mafia Peradilan dalam proses peradilan di Indonesia;

4. Merusak norma, etika dan moralitas para Pegawai Negeri atau Penyelenggara Negara, Hakim dan aparat penegak hukum lainnya;

5. Menimbulkan paradigma buruk di mata masyarakat dan terjadinya ketimpangan sosial, ekonomi dan budaya di Indonesia;

6. Timbulnya peningkatan pelanggaran terhadap Kode Etik Advokat;

7. Mendorong meningkatnya praktikpraktik korupsi lainnya di Indonesia.

a) Penerapan Sanksi Hukum Pidana Terhadap Advokat Pelaku Tindak Pidana Suap Sebagai Wujud 
Hartono: Penerapan Sanksi Hukum Bagi Para Advokat Pelaku Tindak Pidana Suap...

\section{Upaya Kebijakan Penegakan Hukum Di Indonesia}

Pembangunan nasional itu sendiri merupakan suatu proses menuju perbaikan dan perubahan yang jauh lebih baik. Proses pembangunan yang dilaksanakan tentunya akan membawa perubahan kondisi sosial masyarakat yaitu dari masyarakat tradisional menjadi masyarakat yang modern mengikuti perkembangan zaman, dimana tentunya perubahan tersebut akan membawa dampak sosial baik positif maupun negatif yang diakibatkan adanya macam-macam tindakan yang dilakukan oleh anggota masyarakat termasuk tindakan perbuatan melawan hukum/melanggar hukum (hukum pidana) di Indonesia. Sanksi pidana yang ringan membuat pemidanaan itu tidak efektif dan tidak membuat pelaku jera mengulangi perbuatannya (R. Dyatmiko Soemodiharjo, 2008: 47). Lain dari pada itu pidana yang ringan tidak mampu mencegah orang lain melakukan korupsi. Sanksi pidana sebenarnya ditujukan supaya masyarakat mematuhi peraturan serta norma-norma dan tidak melakukan perbuatan pidana.

Salah satu dampak sosial negatif yang timbul adalah adanya tindak pidana yang mengakibatkan timbulnya berbagai keresahan di tengah-tengah masyarakat dan salah satunya adalah perbuatan suap yang masuk dalam tindak pidana korupsi yang dilakukan oleh Advokat yang lebih cenderung mengakibatkan terhambatnya proses penegakan hukum (mafia hukum/mafia peradilan) di Indonesia, melanggar kode etik profesi Advokat, menimbulkan ketidakpastian hukum dan runtuhnya keadilan serta merusak moral bangsa dan ketahanan Nasional. Perbuatan pidana yang cukup sering dilakukan oleh banyak kalangan masyarakat sehari-hari terutama dilakukan oleh Advokat kepada Pegawai Negeri maupun Penyelenggara Negara baik itu pada lingkungan tingkat Eksekutif, Legislatif dan Yudikatif ialah tindak pidana suap.

Pengertian sederhana mengenai perbuatan suap (tindak pidana suap) ialah memberikan sesuatu kepada orang lain untuk mendapatkan keuntungan yaitu dengan memberikan sesuatu dalam bentuk pemberian sejumlah uang/materi kepada pihak-pihak tertentu yang dianggap bisa mempermudah urusan dan kepentingannya dan khususnya suap yang dilakukan oleh Advokat pada umumnya dilakukan untuk memenangkan perkara yang ditanganinya (kepentingan kliennya). Dalam pandangannya, Nico Andrianto dan Ludy Prima Johansyah menyebutkan bahwa "Budaya Jahiliah" korupsi menyebar seperti kanker yang menggerogoti tubuh bangsa Indonesia (Nico Andrianto dan Ludy Prima Johansyah, 2010:6). Dari Sabang sampai Merauke, bangsa ini seolah dipersatukan dengan semangat korupsi. Ia menyelusup liar di tengah era otonomi daerah saat ini, dengan berbagai nama/sebutan, diantaranya: uang pulsa, uang rokok, uang kopi dan sebutan-sebutan lain di setiap daerah.

Salah satu tujuan diberlakukannya UU PTPK di Indonesia adalah untuk 
menghindari dari hal-hal yang berkaitan dengan pola atau modus operandi korporasi dalam melakukan suap, baik modus operandi pemberian suap yang dilakukan secara langsung maupun tidak langsung dalam berbagai bentuk yang terjadi di Indonesia. Dalam kenyataannya penerapan hukum di Indonesia masih terkesan carut marut dan jauh dari kata sempurna, dapat dikatakan bahwa sebenarnya akar permasalahannya dapat disebabkan oleh beberapa hal diantaranya yaitu karena faktor sistem manajemen peradilan, perangkat hukum, inkonsistensi penegakan hukum, intervensi kekuasaan dan politik serta perlindungan hukum yang sesuai prosedur masih jauh dari halhal yang diharapkan dalam era reformasi hukum di Indonesia dan hal ini dapat terlihat dari adanya tindakan-tindakan penyuapan di sana sini dalam ruang lingkup pengadilan yang berjalan penuh dengan konspiratif jahat dalam setiap proses hukum yang ada dan berlangsung selama ini khususnya dilakukan oleh Advokat.

Penerapan sanksi hukum pidana untuk Advokat yang telah melakukan tindak pidana suap di Indonesia, yaitu dengan adanya pemberian/penjatuhan sanksi hukum pidana yang dimana hal tersebut merupakan langkah dan strategi yang tepat untuk memberikan adanya penegakan hukum yang seutuhnya khususnya dalam hal kepastian hukum pidana itu sendiri. Penyuapan itu sendiri merupakan jenis tindak pidana korupsi yang berarti masuk dalam tindak pidana khusus sehingga hukum pidana yang berada di luar kodifikasi KUHP. Sepanjang tidak ada ketentuan lain di dalam peraturan perundang-undangan hukum pidana khusus, maka hukum pidana formil sebagai pelaksanaan hukum materiil dalam peraturan perundangundangan hukum pidana khusus tersebut, tetap berlaku hukum pidana formil dalam kodifikasi KUHAP. Tentang hal ini, dalam hukum pidana korupsi (tindak pidana suap) ditegaskan dalam ketentuan Pasal 26 UU PTPK yang menyebutkan bahwa: Tindak pidana korupsi dengan mekanisme penyidikan, penuntutan dan pemeriksaan di dalam pengadilan dilakukan berdasarkan hukum acara pidana yang berlaku, kecuali ditentukan lain dalam undang-undang ini.

Dalam proses penyidikan dan penuntutan mengenai perbuatan tindak pidana korupsi (tindak pidana suap) di Indonesia dilakukan oleh KPK. KPK juga mempunyai peran penting yaitu melakukan tindakan-tindakan pencegahan tindak pidana korupsi.

Dalam hal penyidikan yang diatur dalam KUHAP dan UU PTPK, pada prinsipnya terdapat ketentuan-ketentuan perbedaan yang mendasar dari UU PTPK yaitu tentang kekhususannya mengenai penyidikan yaitu terdapat dalam ketentuan Pasal 28 UU PTPK yang menyatakan bahwa keterangan tersangka wajib diberikan dan ada sanksinya jika tidak diberikan oleh tersangka dan hal ini tidak seperti pada KUHAP. Dalam KUHAP, ditentukan bahwa tersangka (pelaku tindak pidana suap) dalam penyidikan dimintai keterangan apapun yang 
Hartono: Penerapan Sanksi Hukum Bagi Para Advokat Pelaku Tindak Pidana Suap...

diperlukan untuk membuat terang dugaan tindak pidana, memberikan keterangan itu bersifat wajib (Pasal 116 ayat 2 KUHAP). Namun, tidak ada sesuatu sanksi apabila tersangka tidak bersedia memberikan keterangan.

Ancaman sanksi hukuman dan tujuan pengenaan sanksi terhadap tindak pidana suap yang dilakukan oleh Advokat terdapat dalam KUHP, UUTPS, UUPTPK yang ancaman sanksi hukumnya beragam, dan dapat dikelompokkan menjadi sebagai berikut :

1. Dalam ketentuan KUHP yaitu :

a) Karena Advokat adalah merupakan subjek hukum yaitu barangsiapa sebagai pemberi suap (Penyuapan Aktif), maka termasuk kategori : (Pasal 209 KUHP) mendapatkan ancaman hukuman pidana penjara selama-lamanya dua tahun delapan bulan atau denda paling banyak empat ribu lima ratus rupiah;

b) Karena Advokat adalah pejabat atau aparat penegak hukum maka termasuk pejabat yang diangkat berdasarkan undang-undang yaitu UUA sebagai penerima suap (Penyuapan Pasif), maka termasuk kategori: (Pasal 418 KUHP) mendapatkan ancaman hukuman pidana penjara paling lama enam bulan atau pidana denda paling banyak empat ribu lima ratus rupiah;

c) Karena Advokat adalah pejabat atau aparat penegak hukum, maka termasuk pejabat yang diangkat berdasarkan undang-undang yaitu UUA sebagai penerima suap
(Penyuapan Pasif), maka termasuk kategori : (Pasal 419 KUHP) mendapatkan ancaman hukuman pidana penjara paling lama lima tahun;

d) Karena Advokat adalah pejabat atau aparat penegak hukum, maka termasuk pejabat yang diangkat berdasarkan undang-undang yaitu UUA sebagai penerima suap (Penyuapan Pasif), maka termasuk kategori : (Pasal 420 ayat (1) KUHP) mendapatkan ancaman hukuman pidana penjara paling lama sembilan tahun, sedangkan (Pasal 420 ayat (2) KUHP) mendapatkan ancaman hukuman pidana penjara paling lama dua belas tahun.

2. Dalam Ketentuan UU TPS

Karena Advokat adalah pejabat atau aparat penegak hukum, maka termasuk pejabat yang diangkat berdasarkan undang-undang yaitu UUA sebagai penerima suap (Penyuapan Pasif), maka termasuk kategori : (Pasal 3 UU TPS) mendapatkan ancaman hukuman pidana penjara selama-lamanya tiga tahun atau denda sebanyak-banyaknya lima belas juta rupiah.

3. Dalam Ketentuan UU PTPK

a) Karena Advokat adalah merupakan subjek hukum yaitu barangsiapa sebagai pemberi suap (Penyuapan Aktif), maka termasuk kategori : (Pasal 5 ayat (1) UU PTPK) mendapatkan ancaman hukuman pidana penjara paling sedikit satu tahun dan paling lama lima tahun dan atau denda paling sedikit lima puluh 
juta rupiah dan paling banyak dua ratus lima puluh juta rupiah;

b) Karena Advokat adalah merupakan subjek hukum yaitu barangsiapa sebagai pemberi suap (Penyuapan Aktif), maka termasuk kategori : (Pasal 6 ayat (1) huruf a UU PTPK) mendapatkan ancaman hukuman pidana penjara paling sedikit tiga tahun dan paling lama lima belas tahun dan pidana denda paling sedikit seratus lima puluh juta rupiah dan paling banyak tujuh ratus lima puluh juta rupiah;

c) Karena Advokat adalah pejabat atau aparat penegak hukum, maka termasuk pejabat yang diangkat berdasarkan undang-undang yaitu UUA sebagai penerima suap (Penyuapan Pasif), maka termasuk kategori : (Pasal 6 ayat (1) huruf $b$ UU PTPK) ;

d) Karena Advokat adalah pejabat atau aparat penegak hukum, maka termasuk pejabat yang diangkat berdasarkan undang-undang yaitu UUA sebagai penerima suap (Penyuapan Pasif), maka termasuk kategori : (Pasal 12 huruf d UU PTPK) ;

e) Karena Advokat adalah merupakan subjek hukum yaitu barangsiapa sebagai pemberi suap (Penyuapan Aktif), maka termasuk kategori : (Pasal 13 UU PTPK) mendapatkan ancaman hukuman pidana penjara paling lama tiga tahun dan atau denda paling banyak seratus lima puluh juta rupiah.
Penerapan sanksi terhadap Advokat sebagai pelaku tindak pindana suap hingga saat ini dapat dikatakan terbatas pada 3 (tiga) ketentuan peraturan perundang-undangan yaitu diatur dalam ketentuan KUHP, UU TPS dan UU PTPK. Dalam ketentuan KUHP, penerapan sanksi hukum pidananya secara jelas diatur dalam ketentuan Pasal 209 KUHP, Pasal 418 KUHP, Pasal 419 KUHP dan Pasal 420 ayat (1) dan (2) KUHP. Selanjutnya juga pada UU TPS diatur dalam ketentuan Pasal 3 UU TPS. Sedangkan dalam UU PTPK diatur dalam ketentuan Pasal 5 ayat (1) UU PTPK, Pasal 6 ayat (1) UU PTPK, Pasal 6 ayat (1) huruf b UU PTPK, Pasal 12 huruf d UU PTPK dan Pasal 13 UU PTPK. Akan tetapi dalam hal ini, pada umumnya, dalam setiap putusan-putusan Hakim selama ini, Advokat akan dikenakan dan penerapan sanksi hukum pidana lebih cenderung menggunakan ketentuanketentuan pasal-pasal yang terdapat dalam UU PTPK karena mengingat bahwa tindakan penyuapan adalah merupakan tindak pidana khusus yang masuk di dalam tindak pidana korupsi.

\section{b) Penerapan Sanksi Kode Etik Advokat Indonesia Terhadap Advokat Yang Telah Melakukan Kegiatan Suap-Menyuap}

Kekacauan dalam sistem peradilan dan upaya penegakan hukum yang dilakukan di Indonesia ditimbulkan karena maraknya aksi penyuapan yang salah satunya dikerjakan oleh Advokat. Ada banyak sekali kasus penyuapan yang banyak melibatkan Advokat yang 
Hartono: Penerapan Sanksi Hukum Bagi Para Advokat Pelaku Tindak Pidana Suap...

tergolong dalam tindak pidana berat. Advokat dalam melakukan penyuapan tidak hanya terpaku pada peraturan perundang-undangan (KUHP, UU TPS dan UU PTPK) saja, akan tetapi, juga berkaitan sekali dengan asas peradilan yang tidak terkontaminasi (bersih) dan tindak pidana berupa gangguan terhadap proses memperoleh keadilan yang juga termasuk kategori kejahatan melawan administrasi peradilan.

Meningkatnya kasus-kasus suap yang dikerjakan oleh seorang Advokat selama ini pada umumnya adalah bahwa Advokat bertindak dan melanggar hukum sebagai pelaku suap (penyuapan aktif) dibandingkan sebagai penerima suap (penyuapan pasif). Secara garis besar tidak hanya terfokus pada kejahatankejahatan suap yang belum dirumuskan dalam undang-undang (mala per se). penanggulangan kejahatan suap mala in prohobita tidak akan bisa tercapai tanpa didahului oleh penanggulangan mala per se. oleh karena itu, kebanyakan kejahatan suap mala in prohibita muncul sebagai akumulasi dari kejahatan mala per se terlebih lagi bahwa pelaku kejahatan ini adalah Advokat yang jelas-jelas sebagaimana disebutkan dalam undangundang (UUA) bahwa Advokat adalah merupakan aparat penegak hukum di Indonesia yang tunduk pada ketentuan UUA dan Kode Etik Advokat sebagai pedoman dalam melaksanakan profesinya.

Organisasi Advokat dikonotasikan sebagai sebuah rumah dan tempat bersandar ketika terjadi suatu masalah (Fiska Maulidian Nugroho, 2016).
Advokat sendiri adalah suatu profesi terhormat dan mulia (officium nobile) sekaligus juga sebagai aparat penegak hukum di Indonesia sebagaimana disebutkan dalam ketentuan UUA pada kenyataannya memang memainkan peran penting yang tidak kecil dalam mewujudkan penegakan hukum yang adil dan berwibawa serta menegakkan prinsipprinsip hak-hak asasi manusia walaupun bila dilihat dari dasar hukum yang ada keberadaan Advokat sebelum era reformasi belum diatur secara khusus yaitu masih tersebar dalam berbagai peraturan perundang-undangan baik yang diterbitkan pada zaman dulu (pemerintahan Belanda) danyang dikeluarkan oleh pemerintahan Indonesia saat ini. Akan tetapi, hal ini pada kenyataannya juga berbanding lurus dengan peningkatan pelanggaranpelanggaran Kode Etik Advokat dan juga diperparah oleh adanya kenyataan yang tidak bisa dibantah lagi bahwa kenyataannya juga aksi-aksi penyuapan pada saat ini justru sangat banyak dilakukan oleh Advokat dalam melakukan dan melaksanakan profesinya sehari-hari ketika membela kliennya. Hal ini tentunya sangat memalukan dan cenderung merusak wibawa profesi Advokat yang diagung-agungkan selama ini di Indonesia.

Dalam perkembangannya, di Indonesia menganggap bahwa hukum adalah "Primadona" dan hal mungkin itu adalah sebuah kalimat yang tidak asing lagi dalam ingatan kita dan sudah sering kita dengar, namun melihat fakta dan 
kenyataan yang terjadi sekarang ini di Indonesia, sangat berbeda dengan yang dibayangkan dan inginkan dari sebuah hukum yang berlaku di Indonesia. Selain itu, dikenal pula bahwa hukum itu adalah "Panglima". Kalimat ini pula yang juga masih melekat dalam setiap ingatan masyarakat Indonesia namun yang terjadi juga sama dengan fakta yang diatas yaitu sangat bertolak belakang sekali pelaksanaannya yaitu terjadinya berbagai bentuk penyelewengan dan pelanggaran tentang pelaksanaannya yang dilakukan oleh berbagai kalangan termasuk dilakukan oleh Advokat.

Penerapan sanksi hukum pidana yang diberikan terhadap Advokat yang melakukan penyuapan diatur di dalam ketentuan peraturan perundang-undangan yaitu dalam ketentuan KUHP, UU TPS dan UU PTPK, tetapi tidaklah cukup untuk memberikan suatu kepastian hukum, penegakan hukum, peradilan yang bersih juga yang tak kalah penting adalah termasuk dari upaya peningkatan profesionalisme profesi Advokat di Indonesia dan ketaatan para Advokat dalam menegakkan Kode Etik Advokat itu sendiri. Kode Etik Advokat Indonesia sangat diperlukan mengingat pola kerja dari setiap profesi sangat tergantung dari adanya hal-hal tertentu yang harus dijunjung tinggi oleh yang bersangkutan dan berupaya untuk menghindari pelanggaran hukum termasuk juga mengenai pelanggaran kode etik profesi.

Dalam konteks ini, dalam realitas mudah dijumpai bahwa terdapat suatu tuntutan mulia yang diproyeksikan dalam setiap kerangka kerja dan profesi (Advokat), yakni bagaimana suatu pekerjaan itu tidak sampai meninggalkan kesulitan bagi klien atau pemburu jasa (pencari keadilan), tetapi bagaimana suatu pekerjaan itu mendapat kawalan dan bimbingan moral sehingga pekerjaan dimaksud dapat dinikmati kemanfaatannya oleh pihak-pihak yang membutuhkan. Seseorang yang berprofesi sebagai Advokat atau yang lebih dikenal pengacara yang melakukan penyuapan tentunya dalam tatan hukum positif yang berlaku di Indonesia adalah merupakan perbuatan yang sangat tercela yang sangat dilarang oleh undang-undang (KUHP, UU TPS dan UU PTPK) juga sangat bertentangan dengan kaidah-kaidah moral etika profesi Advokat sebagai bagian dari aparat penegak hukum di Indonesia.

Landasan etika itu, esensinya mengikat pada pelaku pekerjaan atau profesi (Abdul Wahid dan Moh. Muhibbin, 2009: 111). Keterikatan seseorang ini di orientasikan suatu pekerjaan dan profesi tidak dijadikan kesempatan untuk melakukan hal-hal yang menyakiti masyarakat, tidak manusiawi dan tidak bermoral. Kode etik adalah tatan moral yang dibuat sendiri oleh kelompok profesi tertentu khusus bagi anggotanya. Tatanan tersebut mengikat intern anggotanya. Isi dari kode etik berisi perintah baik berupa larangan dan juga sebagai pedoman dalam menjalankan profesinya. Perintah yang berupa larangan apabila dilanggar oleh anggotanya akan mendapat sanksi dari 
Hartono: Penerapan Sanksi Hukum Bagi Para Advokat Pelaku Tindak Pidana Suap...

organisasi profesi tersebut melalui mekanisme persidangan khusus untuk itu.

Penerapan sanksi kode etik terhadap Advokat yang terlibat menjadi pelaku penyuapan (penyuapan aktif) maupun sebagai penerima suap (penyuapan pasif) sangat perlu dilakukan sebagaimana amanat yang terkandung dalam ketentuan Undang-Undang Advokat (UUA) dan (Kode Etik Advokat Indonesia) KEAI. Dalam Pasal 6 UUA, khususnya dalam ketentuan huruf $d$, e dan $\mathrm{f}$, maka dapat terlihat bahwa hal ini sangat erat kaitannya dengan tindakan Advokat melakukan penyuapan yang bisa dikategorikan bahwa tindakan-tindakan seorang Advokat telah melanggar peraturan perundang-undangan/perbuatan tercela serta telang melanggar sumpah jabatan Advokat yang sangat dilarang dalam ketentuan UUA dan KEAI.

Adapun jenis tindakan/sanksi yang dikenakan terhadap Advokat dapat berupa: teguran lisan, teguran tertulis, pemberhentian sementara dari profesinya selama 3 (tiga) sampai 12 (dua belas) bulan, dan pemberhentian tetap dari profesinya (Pasal 7 UUA). Advokat yang diberhentikan secara tetap dalam profesinya disebabkan oleh beberapa hal yaitu: atas permohonan sendiri, di jatuhi hukuman yang telah mempunyai kekuatan hukum tetap diancam dengan hukuman 4 (empat) tahun atau lebih, dan Panitera Pengadilan Negeri menyampaikan salinan putusan tersebut kepada Organisasi Advokat (Pasal 10 UUA).

Pengawasan atas pelanggaran terhadap ketentuan pasal-pasal Kode Etik dilaksanakan secara eksplisit oleh Dewan Kehormatan yang terdiri dari 2 (dua) instansi, pada tingkat pertama adalah Dewan Kehormatan Cabang dan pada tingkat kedua atau tingkat banding disebut Dewan Kehormatan Pusat. Keputusan Dewan Kehormatan Cabang dapat diajukan banding pada Dewan Kehormatan Pusat yang keputusannya merupakan hasil akhir yang tidak dapat diganggu gugat. Namun demikian, Dewan Kehormatan Pusat dapat menerima langsung permohonan pihak-pihak yang bersangkutan dalam persengketaan mereka, asalkan permohonan mereka dilampiri kedua pihak. Adapun Advokat yang melanggar Kode Etik disebut sebagai Teradu sedangkan yang melaporkan Advokat yang melanggar Kode Etik Advokat disebut sebagai Pengadu. Adapun tata cara pengaduan dilakukan sebagaimana disebutkan dalam ketentuan Pasal 12 KEAI.

Menurut ketentuan Pasal 16 KEAI, disebutkan bahwa :

1) Adapun sanksi-sanksi hukuman yang dapat diberikan dalam keputusan dapat berupa :

a. Peringatan Biasa.

b. Peringatan Keras.

c. Pemberhentian sementara untuk waktu tertentu.

d. Pemecatan dari keanggotaan organisasi profesi.

2) Dengan pertimbangan atas berat atau ringannya sifat pelanggaran Kode Etik Advokat dapat dikenakan sanksi :

a. Peringatan biasa bilamana sifat pelanggaran tidak berat.

b. Peringatan keras bilamana sifat pelanggaran berat atau 
karena mengulangi kembali melanggar Kode Etik dan atau tidak mengindahkan sanksi peringatan yang pernah diberikan.

c. Pemberhentian sementara untuk tertentu bilamana sifat pelanggarannya berat, tidak mengindahkan dan tidak menghormati ketentuan Kode Etik atau bilamana setelah mendapat sanksi berupa peringatan keras masih mengulangi melakukan pelanggaran Kode Etik.

d. Pemecatan dari keanggotaan organisasi profesi bilamana dilakukan pelanggaran Kode Etik dengan maksud dan tujuan merusak citra serta martabat kehormatan profesi Advokat yang wajib dijunjung tinggi sebagai profesi yang mulia dan terhormat.

3) Pemberian sanksi pemberhentian sementara untuk waktu tertentu harus di ikuti larangan untuk menjalankan profesi Advokat di luar maupun di muka pengadilan.

4) Terhadap mereka yang dijatuhi sanksi pemberhentian sementara untuk waktu tertentu dan atau pemecatan dari keanggotaan organisasi profesi disampaikan kepada Mahkamah Agung untuk diketahui dan dicatat dalam daftar Advokat.

Penerapan sanksi hukum pidana bagi para Advokat yang mengerjakan suatu perbuatan penyuapan, maka yang tak kalah penting diketahui bahwa penerapan sanksi Kode Etik Advokat baru dilakukan apabila adanya kekuatan hukum tetap (inckracht) dari pengadilan yang menyatakan bahwa Advokat tersebut telah bersalah melakukan penyuapan dan dikenakan hukuman pidana barulah sanksi
Kode Etik Advokat baru bisa dijalankan oleh Organisasi Advokat melalui putusan Dewan Kehormatan baik itu sanksi Peringatan Ringan, Peringatan Keras, Pemberhentian Sementara dan Pemberhentian Tetap dari keanggotaan organisasi advokat.

Pengaturan yang terdapat dalam ketentuan UUA dan KEAI dapat ditemukan bahwa yang menjadi hukum tertinggi bagi Advokat adalah KEAI dalam menjalankan profesinya. Atas hal ini, maka profesi Advokat harus mencerminkan prinsip-prinsip hukum dan tidak bisa lepas dari ketentuan KEAI sehingga setiap tindakannya tetap berpegang teguh dan pengakuan serta kepatuhan/ketaatan pada prinsip-prinsip yang diatur dalam ketentuan KEAI di Indonesia agar tidak melakukan tindakantindakan yang merugikanter lebih lagi tidak terlibat dalam tindak pidana suap dalam upaya penegakan hukum melalui penerapan sanksi hukum pidana yang diatur dalam ketentuan KUHP, UU TPS dan UU PTKP dan juga sebagai upaya kebijakan penegakan Kode Etik profesi Advokat yang seutuhnya tanpa bisa ditunda dan ditawar-tawar lagi pelaksanaannya untuk menjadikan bahwa Indonesia sejatinya adalah merupakan Negara Hukum.

\section{SIMPULAN}

Dari hasil analisa, uraian dan pembahasan mengenai penerapan sanksi hukum bagi para Advokat pelaku tindak pidana suap dalam sistem hukum positif di Indonesia yang telah dilakukan, maka 
Hartono: Penerapan Sanksi Hukum Bagi Para Advokat Pelaku Tindak Pidana Suap...

dapat diperoleh kesimpulan yaitu sebagai berikut:

1. Pengaturan hukum mengenai tindak pidana suap dalam sistem hukum positif di Indonesia hingga saat ini memang kenyataannya masih belum diatur secara jelas, tegas dan khusus pengertian dan pengaturannya. Akan tetapi secara umum, tindak pidana suap telah diatur ke dalam 3 (tiga) jenis peraturan perundang-undangan yang berlaku di Indonesia pada saat ini yaitu terdapat dalam ketentuan KUHP, UU TPS dan UU PTPK.

2. Adapun untuk penerapan sanksi hukum bagi para Advokat pelaku tindak pidana suap dalam sistem hukum positif di Indonesia terdapat ada 2 (dua) jenis sanksi yang dapat diterapkan kepada Advokat yaitu penjatuhan hukuman pidana sebagaimana yang diatur dalam ketentuan Pasal 209 KUHP, Pasal 418 KUHP, Pasal 419 KUHP, Pasal 420 ayat (1) dan (2) KUHP, Pasal 3 UU TPS, Pasal 5 ayat (1) UU PTPK, Pasal 6 ayat (1) UU PTPK, Pasal 6 ayat (1) huruf b UU PTPK, Pasal 12 huruf d UU PTPK dan Pasal 13 UU PTPK. Selain itu, bagi Advokat yang melakukan tindak pidana suap juga dapat dilakukan penerapan sanksi Kode Etik Advokat sebagai hukum tertinggi yang harus dilaksanakan, kepatuhan dan ketaatan pada prinsipprinsip yang diatur dalam ketentuan KEAI yang berlaku di Indonesia agar tidak melakukan tindakan-tindakan yang merugikan harkat dan martabat kehormatan profesi Advokat termasuk di dalamnya tidak terlibat dalam tindak pidana suap dalam menjalankan profesinya sehari-hari sebagai profesi yang mulia dan terhormat (officium nobile) sekaligus juga salah satu bagian catur wangsa aparat penegak hukum yang diakui di Indonesia.

\section{UCAPAN TERIMAKASIH}

Penulis kepada semua pihak yang telah mendukung penulisan artikel ini, terutama kepada Ibu Prof. Dr. Lanny Kusumawati, Dra., S.H., M.Hum., Dr. Suhartati, S.H., M.Hum., dan Sriwati, S.H., M.Hum yang telah membimbing penulis dalam mengerjakan tesis dan serta kepada tenaga pengajar dan teman-teman mahasiswa Program Pascasarjana Fakultas Hukum Universitas Surabaya.

\section{DAFTAR PUSTAKA}

\section{Buku-buku}

Andrianto Nico dan Johansyah Prima Ludy, Korupsi Di Daerah Modus Operandi \& Peta Jalan Pencegahannya, Cetakan Pertama, Putra Media Nusantara, Surabaya, 2010.

Marzuki, Peter Mahmud, Penelitian Hukum, KencanaPranada Media Group, Jakarta, 2008.

Rahardjo Satjipto, Ilmu Hukum, Cetakan Keenam,Citra Aditya Bakti, Bandung, 2006.

Soemodiharjo Dyatmiko. R, Mencegah Dan Memberantas Korupsi Mencermati Dinamikanya Di Indonesia, Cetakan Pertama, Prestasi Pustaka, Jakarta, 2008. 
Wahid Abdul, Etika Profesi Hukum Rekonstruksi Citra Peradilan Di Indonesia, Cetakan Pertama, Bayumedia Publishing, Malang, 2009.

\section{Jurnal}

Agus Raharjo \& Sunaryo, Penilaian Profesionalisme Advokat Dalam Penegakan Hukum Melalui Pengukuran Indikator Kinerja Etisnya, Jurnal Media Hukum, Vol.21 2014

Erman Rajagukguk, Advokat Dan Pemberantasan Korupsi, Jurnal Hukum Ius Quia Iustum, Vol 15 2008

Fiska Maulidian Nugroho, Integritas Advokat dan Kebebasannya Dalam Berprofesi: Ditinjau dari Penegakan Kode Etik Advokat, Rechtidee, Vol 112016

Muryanti, Tindakan Korupsi Sebagai Tindakan Imoral Dalam Perspektif Fungsional (Kajian Film Korupsi Dan Kita:Rumah Perkara), Profetik Jurnal Komunikasi, Vol 112018.

Odie Faiz Guslan, Tinjauan Yuridis Mengenai Batasan Antara Perbuatan Maladministrasi Dengan Tindak Pidana Korupsi, Jurnal Cendekia Hukum, Vol.4 2018.

RB. Soemanto, Sudarto, Sudarsana, Pemahaman Masyarakat Tentang Korupsi, Yustisia Jurnal Hukum, Vol 32014

Russel Butarbutar, Modus Operandi Dan Pertanggung Jawaban Pidana Suap
Korporasi, Jurnal Ilmu Hukum, Vol. 42017.

Sjahruddin Rasul, Penerapan Good Governance Di Indonesia Dalam Upaya Pencegahan Tindak Pidana Korupsi, Jurnal Mimbar Hukum, Vol 212009

Vidya Prahassacitta, Tinjauan Atas Kebijakan Hukum Pidana Terhadap Penyuapan Di Sektor Privat Dalam Hukum Nasional Indonesia: Suatu Perbandingan Dengan Singapura, Malaysia Dan Korea Selatan, Jurnal Hukum dan Pembangunan, Vol 47 2017

\section{Peraturan Perundang-undangan :}

Undang-Undang Nomor 1 Tahun 1946 Tentang Peraturan Hukum Pidana

Undang-Undang Republik Indonesia Nomor 11 Tahun 1980 Tentang Tindak Pidana Suap

Undang-Undang Republik Indonesia Nomor 20 Tahun 2001 Tentang Perubahan Atas Undang-Undang Republik Indonesia Nomor 31 Tahun 1999 Tentang Pemberantasan Tindak Pidana Korupsi

Undang-Undang Republik Indonesia Nomor 18 Tahun 2003 Tentang Advokat

Kode Etik Advokat. 